\title{
GH gene expression in the submaxillary gland in normal and Ames dwarf mice
}

\author{
A Pérez-Romero, E Dialynas ${ }^{1}$, F Salame, A Amores, L Vidarte, \\ A Bartke ${ }^{1}$, C Ariznavarreta and J A F Tresguerres \\ Department of Physiology, Faculty of Medicine, Universidad Complutense de Madrid, 28040 Madrid, Spain \\ ${ }^{1}$ Department of Physiology, School of Medicine, Southern Illinois University, Carbondale, Illinois, USA \\ (Requests for offprints should be addressed to J A F Tresguerres; Email: guerres@eucmax.sim.ucm.es)
}

\begin{abstract}
High local GH-releasing hormone (GHRH) levels are capable of inducing transdifferentiation in salivary cells to synthesize GH. However, the factors implicated in this process remain unknown. To study this subject, normal and Ames dwarf mice were implanted in the submaxillary gland with a slow release pellet releasing $21 \mu \mathrm{g}$ GHRH (1-29)- $\mathrm{NH}_{2}$ /day for 2 months. Control animals received placebo pellets at the same site. After 60 days, heart blood was collected and submaxillary glands were removed. Circulating levels of GH and IGF-I were significantly decreased $(P<0.05)$ in dwarf mice in comparison with controls, and GHRH treatment did not modify either of these two parameters. Controls carrying GHRH pellets showed a significantly higher GH content $(P<0 \cdot 05)$ in the submaxillary gland than the placebo-treated normal mice. There were no differences between the IGF-I concentrations of placebo- and GHRH-treated salivary tissue
\end{abstract}

from normal mice. Analysis of GH mRNA by RT-PCR followed by Southern blot revealed that GH transcripts were present in the salivary gland samples carrying the placebo pellets in both normal and dwarf mice. The expression of $\mathrm{GH}$ was significantly $(P<0 \cdot 05)$ increased by the GHRH pellets in salivary tissue from normal mice, but not in submaxillary glands from dwarf mice. Pit-1 mRNA was not detected in the GHRH-treated glands of normal and dwarf mice by RT-PCR or by Southern blot. Using these highly sensitive methods, we have been able to detect the transcription of both GH and Pit-1 in pituitaries from Pit-1-deficient Ames dwarf mice. The present experiment demonstrates that salivary tissue synthesizes $\mathrm{GH}$ when it is exposed to the influence of GHRH. Both basal and GHRH-induced salivary GH expression appear to be independent of Pit-1.

Journal of Endocrinology (2001) 169, 389-396

\section{Introduction}

In previous studies from our group, we have reported that adult rat salivary tissue is capable of synthesizing certain pituitary hormones when stimulated by hypothalamic factors both in vivo and in vitro (Tresguerres et al. 1999a,b). This effect seems to be due to a transdifferentiation process of salivary tissue cells.

Rat parotid gland cells in culture, submitted to hypothalamic extracts or synthetic hypothalamic hormones, were able to synthesize and secrete some pituitary hormones including luteinizing hormone $(\mathrm{LH})$, prolactin, and growth hormone (GH) (Tresguerres et al. 1999a, Fernandez et al. 1994). In these experiments, the effect was less marked when synthetic factors were used, probably indicating the existence of unknown enhancers in the crude hypothalamic extract. The capability of adult rat salivary cells to produce pituitary hormones was confirmed by in vivo studies, in which rat submaxillary glands were also able to synthesize GH after local GH-releasing

hormone (GHRH) stimulation (Tresguerres et al. 1999b). However, the factors implicated in the GH-induction process and the characteristics of this salivary GH remain unknown.

GHRH-induced GH synthesis in the pituitary has been found to be mediated by the transcription factor Pit-1, through the activation of the GH gene (Karin et al. 1990, Ruvkun 1992). Pit-1 also activates the genes of prolactin and of the $\beta$-subunit of thyrotrophin (Fox et al. 1990, Steinfelder et al. 1991), and controls the differentiation of somatotropes, lactotropes and thyrotropes during pituitary development (Andersen \& Rosenfeld 1994). Ames dwarf mice are an experimental model of pituitary dwarfism caused by an autosomal recessive mutation that produces a dramatic deficiency in Pit-1 (Sornson et al. 1996). As a consequence of this, these animals are GH and prolactin deficient, exhibit a hypothyroid condition and lack the pituitary cell types responsible for production of these hormones (Bartke 1964, Slabaugh et al. 1981). 
The present study was undertaken to evaluate the implication of Pit-1 in the locally GHRH-induced transdifferentiation process in submaxillary glands of adult normal and Ames dwarf mice. In addition, salivary GH mRNA has also been analyzed by both Southern blot hybridization and restriction endonuclease digestion.

\section{Materials and Methods}

\section{Animals and accommodation}

Female Ames dwarf mice $(d f / d f)$ of 1.5-2 months of age and their normal siblings (DF/ - ) were used in this experiment. The mice were born and raised in the breeding colony at Southern Illinois University at Carbondale, Carbondale, IL, USA. The animals were housed four to five per cage in a room with controlled light (12 h light:12 h darkness cycle, lights on at $0630 \mathrm{~h}$ ), temperature $\left(22 \pm 1{ }^{\circ} \mathrm{C}\right)$ and humidity $(40 \%)$. Mice were given free access to a nutritionally balanced diet (Tekland; Harlan Sprague-Dawley Inc., Madison, WI, USA) and tap water.

\section{Experimental designs}

The studies were conducted in accordance with the principles and procedures outlined in the NIH Guide for the Care and Use of Laboratory Animals. The protocol for animal use was also approved by the committee of Southern Illinois University at Carbondale with the reference number 95-034.

Thirty-four mice were implanted with a slow release pellet (Innovative Research of America, Toledo, $\mathrm{OH}$, USA) in the right submaxillary gland under light anesthesia, and divided into the following four groups. One group of controls $(n=7)$ and another group of dwarf $(n=10)$ mice received a pellet loaded with $1.25 \mathrm{mg}$ GHRH (1-29)- $\mathrm{NH}_{2}$ (Geref; Serono, Madrid, Spain) allowing a continuous peptide release of $21 \mu \mathrm{g} /$ day for 60 days. Two further groups of normal mice $(n=7)$ and dwarf mice $(n=10)$ received a placebo pellet.

After 60 days, the submaxillary glands from normal mice bearing the pellet were dissected under ether anesthesia. Glands were weighed and halved: one half was immediately frozen in liquid nitrogen and kept frozen at $-80{ }^{\circ} \mathrm{C}$ until analyzed by molecular biology techniques, and the other half was kept at $-20{ }^{\circ} \mathrm{C}$ for hormone content measurements using radioimmunoassay (RIA). Because of the small size of the submaxillary gland in Ames dwarf mice we decided to use all the tissue treated with GHRH or placebo pellets for molecular biology studies, since the analysis of salivary GH gene expression was the main objective of the present experiment. Blood was drawn from the heart, centrifuged and the corresponding plasma stored at $-20{ }^{\circ} \mathrm{C}$ for $\mathrm{GH}$ and insulin-like growth factor-I (IGF-I) determination using specific RIA methods. The mice were killed by decapitation and their pituitary glands carefully removed and also kept frozen at $-80{ }^{\circ} \mathrm{C}$ until analyzed.

\section{Hormonal and protein determinations}

GH, IGF-I, GHRH and protein contents were measured in homogenates of submaxillary glands. GH and IGF-I were also determined in plasma samples.

The homogenates were obtained by sonication (Branson Sonifier 450) in 0.01 M phosphate sodium buffer, $\mathrm{pH} 3.5$. One half of this extract was centrifuged for $15 \mathrm{~min}$ at $1500 \mathrm{~g}$ at $4{ }^{\circ} \mathrm{C}$ and used to measure GH, IGF-I and total protein contents, and the other half was boiled for $5 \mathrm{~min}$, centrifuged and the supernatants lyophilized and stored frozen until analyzed for GHRH.

Mouse GH determinations were carried out using an RIA method adapted from that reported by Lima et al. (1993) for rat GH. Mouse GH-AFP 10783-B, generously provided by Dr A F Parlow (Harbor-University of California, Torrance, CA, USA), was used as a reference preparation and also for iodination using the lactoperoxidase method (Thorell \& Johansson 1971). The antibody used was anti-rGH-S5 supplied by the National Hormone and Pituitary Program (NIDDK, Baltimore, MD, USA). The sensitivity of the standard curve was $5 \mathrm{pg} /$ tube. All samples were included in the same assay, and the intra-assay coefficient of variation was $4.9 \%$.

Plasma IGF-I levels and IGF-I concentrations in the homogenates of the submaxillary glands were determined by a double-antibody RIA using a non-equilibrium technique (Daughaday et al. 1980). IGF-binding proteins (IGFBPs) in both types of samples were separated by acid-ethanol extraction before the assay, according to the method of Daughaday et al. (1980). Human biosynthetic recombinant IGF-I lot A52-EPD-182 provided by Eli Lilly Co. (Indianapolis, IN, USA) was used as the standard and also for iodination, using in this case the chloramine $\mathrm{T}$ method as previously described (Daughaday et al. 1980, Chatelain et al. 1983). Polyclonal rabbit anti-IGF-I antibody UB3-T89 was also supplied by NIDDK. The minimum amount of hormone detectable in the assay was $2 \mathrm{pg} /$ tube and the inter- and intra-assay coefficients of variation were 12.9 and $7 \cdot 8 \%$ respectively.

The validation of both the IGF-I assay and the IGFBP extraction procedure in plasma samples has already been reported by our group (Rol de Lama et al. 1998). Similarly, a further validation procedure was performed with the homogenates of the submaxillary glands in order to confirm that the remaining IGFBPs did not interfere with the assay, according to the 'Recommendations from the 3rd International Symposium on Insulin-like Growth Factors' (Bang et al. 1995). The correlation between the IGF-I reference curve and the dilution series of extracted homogenates was assessed, observing a high parallelism between them. Secondly, high recovery of labelled IGF-I was also demonstrated (85\%) when the radioactive 
preparation was preincubated with several samples before acid-ethanol extraction. Separation of extracted homogenates with dextran-coated charcoal showed that they were $99.3 \%$ free of IGFBPs as compared with $90 \%$ in the unextracted homogenates.

GHRH content in submaxillary homogenates was assayed by a specific RIA, using GHRH (1-29)- $\mathrm{NH}_{2}$ as the standard and iodination by the lactoperoxidase method. Antibody anti-GHRH was prepared in our laboratory by immunizing rabbits with GHRH (1-29)$\mathrm{NH}_{2}$ coupled with hemocyanin with carbodiimide and mixed with Freunds's complete adjuvant (Difco Labs, Detroit, MI, USA) as previously described for other peptides (Goodfriend et al. 1964). GHRH antibody did not show a cross-reaction with glucagon, parathyroid hormone, corticotrophin-releasing hormone, somatostatin, LH-releasing hormone or gastrin, and was used at a final dilution of 1:42 000. The assay was performed following the protocol used by our group for measurement of the same peptide in the hypothalamus (Cardinali et al. 1994). The level of detection of the GHRH assay was $5 \mathrm{pg} /$ tube with inter- and intra-assay coefficients of variation of $14 \cdot 4$ and $12 \cdot 1 \%$.

Total protein content in submaxillary homogenates was determined by the brilliant blue method (Bradford 1976). Coomassie brilliant blue G-250 (Sigma, St Louis, MO, USA) dissolved in ethanol and phosphoric acid was used as a colouring reagent and the reference curve was prepared with bovine serum albumin (BSA) (Sigma). The sensitivity of this assay was $2 \mu \mathrm{g} /$ tube and the inter- and intra-assay coefficients of variation were 5.05 and $1.84 \%$.

\section{$R N A$ isolation and $c D N A$ synthesis by reverse transcription}

Total RNA was extracted from a portion of a mouse submaxillary gland kept at $-80{ }^{\circ} \mathrm{C}$ by a single step acid guanidium thiocyanate-phenol-chloroform method as described elsewhere (Chomczynski \& Sacchi 1987). The integrity of each RNA sample was examined by gel electrophoresis, using a $2 \%$ agarose gel with ethidiumbromide staining. The quantity of total RNA was assessed by spectrophotometric absorbance at $260 \mathrm{~nm}$ (Shimadzu UV-1201).

In addition, RNA was isolated from pituitary glands of normal and Ames dwarf mice. Pituitaries from normal mice were used as a positive control for the amplified product.

Three micrograms of total RNA were utilized for the synthesis of cDNA by reverse transcription (RT), using 18 IU avian myeloblastosis virus reverse transcriptase (Promega Corporation, Madison, WI, USA), 1.5 $\mu \mathrm{M}$ oligo(deoxythymidine) ${ }_{1-15}$ primer (Life Technologies Ltd, Paisley, Strathclyde, UK), $50 \mathrm{mM} \mathrm{KCl,} 10 \mathrm{mM} \mathrm{MgCl}$, $50 \mathrm{mM}$ Tris- $\mathrm{HCl} \mathrm{pH} 8 \cdot 3,10 \mathrm{mM}$ dithiothreitol, $0 \cdot 2 \mathrm{mM}$ of each deoxy-NTP, and $50 \mathrm{IU}$ ribonuclease inhibitor (Recombinant RNAsin; Promega). The reaction mixture was incubated at $42{ }^{\circ} \mathrm{C}$ for $1 \mathrm{~h}$ and at $52{ }^{\circ} \mathrm{C}$ for $30 \mathrm{~min}$.
PCR and Southern blot hybridization

The cDNA was later amplified by polymerase chain reaction (PCR) to study mouse GH, Pit-1 and $\gamma$-actin genes, using specific primers synthesized by Life Technologies Ltd. $\gamma$-Actin gene was used as an example of ubiquitous gene expression to normalize GH signal (Matsubara et al. 1995).

The mouse GH primers were: sense 5' ACTGCTTG GCAATGGCTAC 3' (51-69 nucleotides (nt)) and antisense 5' ATCTTCCAGCTCCTGCATC 3' (505-523 nt), which amplify a 473 base pair (bp) fragment (Linzer \& Talamantes 1985). The Pit-1 primers were: sense $5^{\prime}$ TGG AGTGATGGCAGGCAGTTTAA 3' (201-223 nt) and antisense $5^{\prime}$ TTTCACCCGTTTTTCTCTCTGCCT $3^{\prime}$ (796-819 nt), which amplify a $618 \mathrm{bp}$ fragment (Li et al. 1990). The $\gamma$-actin primers were: sense $5^{\prime}$ ATCTGGC ACCACACCTTCTACAATGAGCTGCG 3' (234-265 nt) and antisense $5^{\prime}$ TCAGGGGGAGCAATGATCTT AATCTTCATCGTG 3' (950-982 nt), which amplify a $748 \mathrm{bp}$ fragment (Peter et al. 1988). All these primers were tested in a BLASTN $1.4 \cdot 11$ computer program to verify the complete match with the corresponding gene sequence (Altschul et al. 1990).

The GH PCR reactions were carried out using an aliquot of $5 \mu \mathrm{l}$ of the resulting RT mixture from submaxillary gland samples and $1.5 \mu \mathrm{l}$ from pituitary, 1 IU Taq polymerase (EcoTaq; Ecogen SRL, Madrid, Spain), $16.6 \mathrm{mM}\left(\mathrm{NH}_{4}\right)_{2} \mathrm{SO}_{4}, 2.5 \mathrm{mM} \mathrm{MgCl} 2,67 \mathrm{mM}$ Tris-HCl pH $8 \cdot 8,0 \cdot 2 \mathrm{mM}$ of each deoxy-NTP and $0.5 \mu \mathrm{M}$ of each specific primer, in a total volume of $50 \mu \mathrm{l}$. Thirty-five cycles of PCR were run using a thermal cycler (Programmable Thermal Controller PTC-100, MJ Research Inc.) according to the following step program: 1 min of denaturation at $94^{\circ} \mathrm{C}, 1 \mathrm{~min}$ of annealing at $53{ }^{\circ} \mathrm{C}$, and $1.5 \mathrm{~min}$ of extension at $72{ }^{\circ} \mathrm{C}$. Amplification was completed with an additional extension step at $72{ }^{\circ} \mathrm{C}$ for $15 \mathrm{~min}$. Pit-1 and $\gamma$-actin PCR were performed following the same protocol as that described for $\mathrm{GH}$ but the number of cycles and the temperature of the annealing process were changed. For Pit-1, $10 \mu \mathrm{l}$ cDNA from salivary glands and $5 \mu \mathrm{l}$ from pituitaries were submitted to 40 cycles using $63^{\circ} \mathrm{C}$ as the annealing temperature. ã-Actin PCR was performed with $5 \mu \mathrm{l}$ cDNA for every sample, running 35 cycles at $70{ }^{\circ} \mathrm{C}$.

Two kinds of negative control were run in each RT-PCR reaction to confirm that no contamination had occurred during the course of both procedures. In the first control assay, total RNA was omitted in the RT and, in the second one, cDNA was omitted in the PCR method. The experiment was considered useful only when no band was observed in the negative control lane on the agarose gel. In addition, to avoid false identification of PCR products derived from co-amplified genomic DNA contaminants, PCR primers were designed from two adjacent exons for each of the genes analyzed. 
The PCR products were visualized in $2 \%$ agarose gel electrophoresis with ethidium-bromide staining under UV light (Fisher FB-TIV-88).

The agarose gel was blotted onto a Hybond-N+ nylon membrane (Amersham Life Science, Amersham, Bucks., UK) under $0.5 \mathrm{M} \mathrm{NaOH}$ overnight. The prehybridization was performed for $3 \mathrm{~h}$ at $57^{\circ} \mathrm{C}$ for GH, Pit- 1 and $\gamma$-actin in $50 \times$ Denhardt's solution (1\% Ficoll, $1 \%$ polyvinylpyrrolidone and 1\% BSA), $20 \times$ SSPE, 10\% SDS and $10 \mathrm{mg} / \mathrm{ml}$ denatured salmon sperm DNA according to the procedure of Sambrook et al. (1989). Hybridization was carried out in the same buffer as that in the prehybridization step using a ${ }^{32} \mathrm{P}$-labelled specific probe for $20 \mathrm{~h}$ at $57^{\circ} \mathrm{C}$ for $\mathrm{GH}$ (probe sequence $5^{\prime}$ TTGCTTCGCTTC TCGCTGCT $3^{\prime}, 359-378$ nt from Linzer \& Talamantes 1985), Pit-1 (5' AGCAGGTCGGAGCTTTGTAC 3', 593-612 nt from Li et al. 1990) and $\gamma$-actin (5' TCTATG AGGGCTACGCCCTT 3', 475-494 nt from Peter et al. 1988). After the hybridization, the membrane was washed five times in $6 \times \mathrm{SSC}$ for $20 \mathrm{~min}$ at the corresponding temperature. The blots were exposed overnight to $\mathrm{X}$-ray film at $-80^{\circ} \mathrm{C}$ with two intensifying screens and developed by standard procedures.

The resultant autoradiography was analyzed and quantitated using Hewlet Packard Descan II and PC Image computer programs. The intensity of the GH signal was normalized to the $\gamma$-actin band and plotted as arbitrary units.

\section{Restriction endonuclease digestion}

Ten microlitres of PCR products from normal pituitaries and from submaxillary glands were digested by AvaI (Promega) using 2 IU of the restriction enzyme. The reaction mix was incubated for $5 \mathrm{~h}$ at $37^{\circ} \mathrm{C}$. Restriction products, together with undigested samples, were electrophoresed in a $2 \%$ agarose gel stained with ethidium bromide and examined as described above.

\section{Statistical analysis}

Results are presented as means \pm S.E.M. Statistical analysis was performed by two-factor analysis of variance. Student's $t$-test was used when values of only two groups were compared. The significance was determined using $P<0 \cdot 05$.

\section{Results}

\section{Plasma GH and IGF-I levels}

As shown in Table 1, plasma concentrations of GH and IGF-I were significantly decreased $(P<0 \cdot 05$ in both cases) in Ames dwarf mice with respect to those seen in controls. GHRH treatment did not modify either of these two parameters in normal or dwarf mice (Table 1).
Table 1 Circulating GH and IGF-I plasma levels at the end of the experiment in Ames normal and dwarf mice receiving a placebo or GHRH pellet in the submaxillary gland. Values represent the means \pm S.E.M. The number of animals in each group is shown in parentheses

\begin{tabular}{|c|c|}
\hline GH $(\mathrm{ng} / \mathrm{ml})$ & IGF-I (ng/ml) \\
\hline $2 \cdot 9 \pm 1 \cdot 2$ & $264 \cdot 6 \pm 16$ \\
\hline $2 \cdot 3 \pm 1 \cdot 3$ & $250 \cdot 8 \pm 11$ \\
\hline $0 \cdot 67 \pm 0 \cdot 1^{*}$ & $56 \pm 4 \cdot 3^{*}$ \\
\hline $0 \cdot 7 \pm 0.11^{*}$ & $47 \pm 7 \cdot 7^{*}$ \\
\hline
\end{tabular}

${ }^{*} P<0 \cdot 05$ vs normal mice.

\section{Hormonal contents and weight of submaxillary glands}

$\mathrm{GH}$ content in submaxillary glands (ng/mg protein) of normal mice implanted with GHRH pellets was significantly higher $(P<0 \cdot 05)$ than in glands treated with placebo pellets (Fig. 1A). However, there were no significant differences in IGF-I contents (ng/mg protein) between placebo- and GHRH-treated salivary glands (Fig. 1B).

GHRH levels in submaxillary glands treated with this peptide were measured in order to prove that GHRH had been released from the pellets and was present in the tissue. High amounts of radioimmunoassayable GHRH in
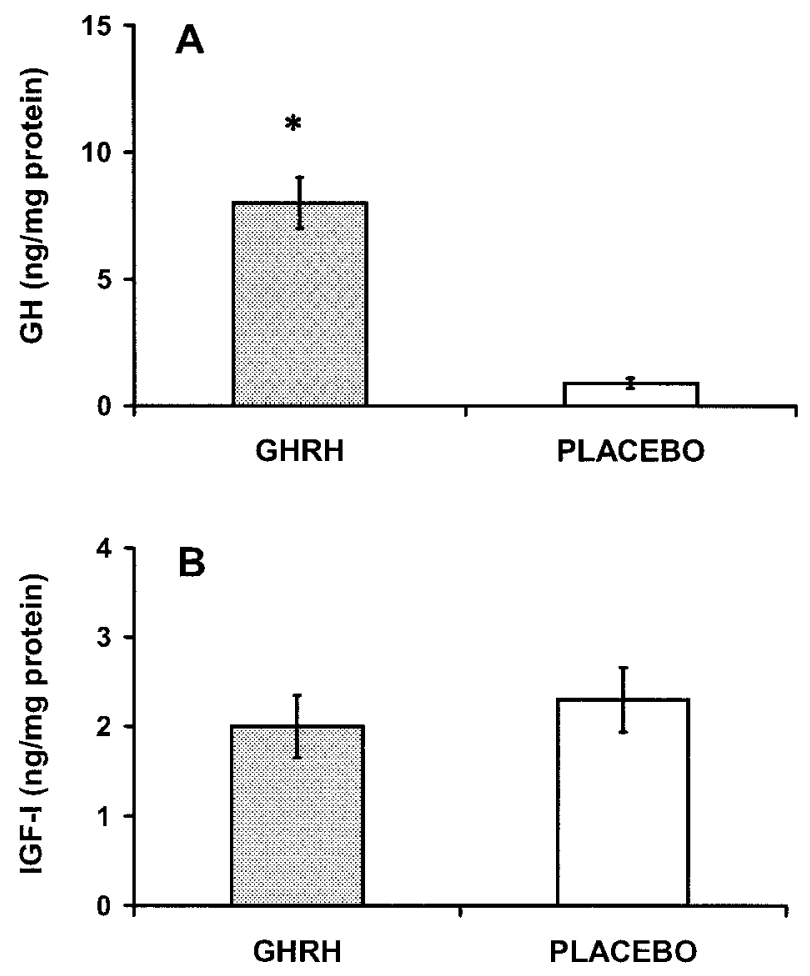

Figure 1 Concentrations of (A) GH and (B) IGF-I ( $\mathrm{ng} / \mathrm{mg}$ protein) in submaxillary glands of normal mice implanted with a GHRH or placebo pellet. Values represent the mean \pm S.E.M. and the number of animals per group was seven. ${ }^{\star} P<0 \cdot 05$ vs placebo-treated mice. 
A

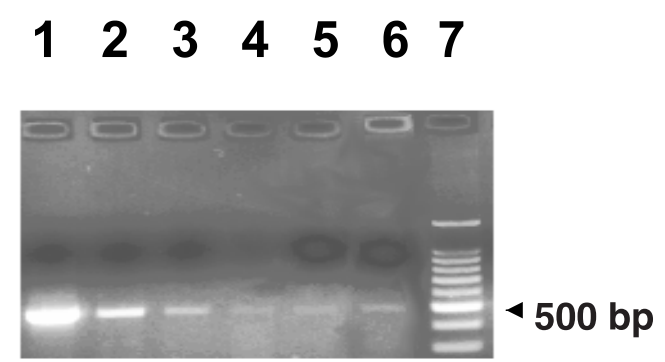

B

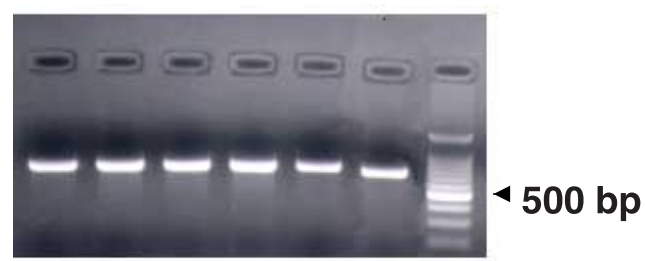

Figure 2 Expression analysis of (A) GH and (B) $\gamma$-actin mRNA by RT-PCR in pituitary and submaxillary glands of normal and Ames dwarf mice. The molecular size of the PCR products was $473 \mathrm{bp}$ for GH mRNA and 749 bp for $\gamma$-actin. Lane 1: pituitary from normal mice. Lanes 2 and 3: GHRH-treated submaxillary glands from normal mice. Lane 4: placebo-treated submaxillary glands from normal mice. Lane 5: GHRH-treated submaxillary glands from dwarf mice. Lane 6: placebo-treated submaxillary glands from dwarf mice. Lane 7: 100 bp ladder.

the GHRH-treated glands were found with an average of $24 \pm 15 \mathrm{ng} / \mathrm{mg}$ protein (ranging from $2 \cdot 6$ to $69 \mathrm{ng} / \mathrm{mg}$ protein). The levels of GHRH in glands bearing a placebo pellet were undetectable.

The weight of submaxillary glands was similar in normal mice treated with GHRH or placebo pellets (GHRH-treated: $70 \pm 6.9 \mathrm{mg}$; placebo-treated: $70 \pm$ $4.3 \mathrm{mg})$. A similar weight in GHRH- and placebo-treated submaxillary glands could also be observed in Ames dwarf mice (GHRH-treated: $23 \pm 3 \mathrm{mg}$; placebo-treated: $19 \pm 1.5 \mathrm{mg})$.

\section{Analysis of GH expression}

$\mathrm{GH}$ and $\gamma$-actin mRNA levels in the pituitaries and submaxillary glands of Ames mice were analyzed by RT-PCR followed by Southern blot. The expected 473 bp GH band was obvious after amplification of cDNA from normal pituitaries. In addition, a band of the same size, although with less intensity than in the pituitary, was observed in the samples obtained from submaxillary glands of GHRH-treated normal mice (Fig. 2A). Surprisingly, a faint but detectable $\mathrm{GH}$ signal could also be seen in the submaxillary glands from placebo-treated normal mice and from placebo- or GHRH-treated dwarf mice (Fig. 2A). The expression levels of the $\gamma$-actin gene were constant in all the tested tissues (Fig. 2B).
A

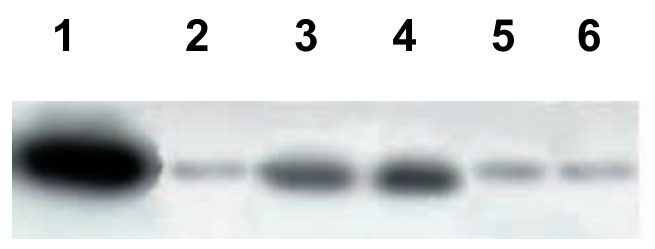

B
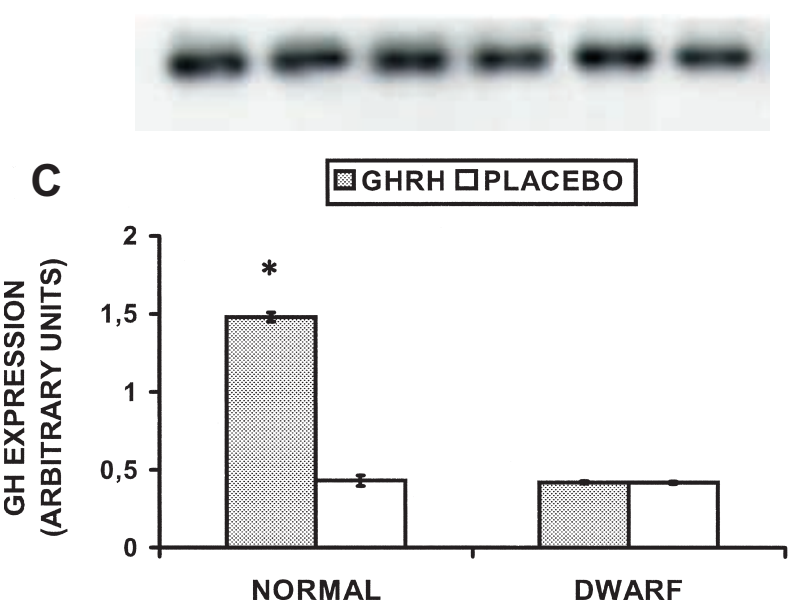

Figure 3 (A) GH and (B) $\gamma$-actin expression in pituitary and submaxillary glands of normal and Ames dwarf mice after Southern blot hybridization. Lane 1: pituitary gland from normal mice. Lane 2: placebo-treated submaxillary gland from normal mice. Lanes 3-4: GHRH-treated submaxillary gland from normal mice. Lane 5: placebo-treated submaxillary gland from dwarf mice. Lane 6: $\mathrm{GHRH}$-treated submaxillary gland from dwarf mice. (C) GH mRNA levels normalized to $\gamma$-actin (arbitrary units) in salivary tissues presented as means \pm S.E.M. GH mRNA level relative to $\gamma$-actin in pituitary from normal mice was $5 \cdot 16$ arbitrary units. The number of samples was seven in both groups of normal mice and ten in those of Ames dwarf mice. ${ }^{*} P<0 \cdot 05$ vs the rest of the groups.

The identity of GH amplification products as well as the differences in the intensity among samples were confirmed by Southern blot hybridization with an internal radiolabelled oligonucleotide. This highly sensitive technique indicates that PCR products of $\mathrm{GH}$ from submaxillary glands were identical to the corresponding pituitary GH cDNAs. Representative Southern blot data comparing GH mRNA from normal pituitaries and from submaxillary glands treated with placebo or GHRH pellets are shown in Fig. 3A. The $\gamma$-actin band corresponding to these samples is presented in Fig. 3B.

$\mathrm{GH}$ and $\gamma$-actin signals obtained by Southern blot analysis were used to quantitate $\mathrm{GH}$ expression. The mean value of GH mRNA normalized to $\gamma$-actin in salivary tissues from normal mice was significantly $(P<0 \cdot 05)$ increased in the GHRH-treated group with respect to that found in placebo-treated glands. However, there were no 


\section{$\begin{array}{lllllll}1 & 2 & 3 & 4 & 5 & 6 & 7\end{array}$}

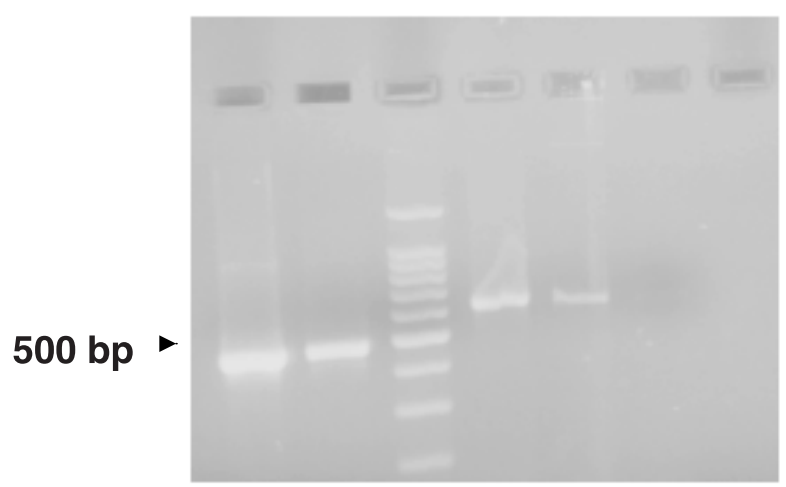

Figure 4 RT-PCR analysis of GH and Pit-1 expression in pituitary and submaxillary gland. GH mRNA levels (473 bp) are shown in lanes 1 and 2, whereas lanes 4, 5, 6 and 7 represent Pit- 1 expression (618 bp). Lanes 1 and 4: pituitary from normal mice. Lanes 2 and 5: pituitary from dwarf mice. Lane 6: submaxillary gland from placebotreated normal mice. Lane 7: submaxillary gland from GHRH-treated normal mice. Lane 3: molecular size markers.

differences between the values observed in glands bearing GHRH or placebo pellets in dwarf mice, which were similar to the levels found in placebo-treated glands from normal mice (Fig. 3C). The GH mRNA level relative to $\gamma$-actin in pituitary from normal mice was $5 \cdot 16$ arbitrary units.

In addition to these studies, analysis of the presence of GH mRNA in pituitaries from normal and Ames dwarf mice was performed. As can be seen in Fig. 4, the $473 \mathrm{bp}$ band was detectable after RT-PCR in the normal pituitary (lane 1) and also in a sample from pooled dwarf pituitary glands (lane 2), although in this case the signal was less intense. GH mRNA was confirmed by Southern blot hybridization in both tissues.

\section{Study of Pit-1 gene expression}

Pit-1 mRNA levels were also monitored by RT-PCR followed by Southern blot in pituitary and submaxillary gland samples from normal and dwarf mice. The amplification of cDNA from normal pituitaries showed a marked Pit-1 band of the predicted size (618 bp) (Fig. 4, lane 4). A less intense but still clear Pit-1 signal was present in pooled pituitaries of dwarf mice (Fig. 4, lane 5). Pit-1 mRNA was absent from the submaxillary gland samples from placebo- (Fig. 4, lane 6) or GHRH-treated (Fig. 4, lane 7) normal mice, and from salivary tissue samples from Ames dwarf mice. The same results appeared after the corresponding Southern blot of the PCR products.

\section{Restriction endonuclease analysis of GH gene expression}

GH PCR products were submitted to enzymatic digestion with AvaI. As can be observed in Fig. 5, PCR samples

\section{$\begin{array}{llllllll}1 & 2 & 3 & 4 & 5 & 6 & 7 & 8\end{array}$}

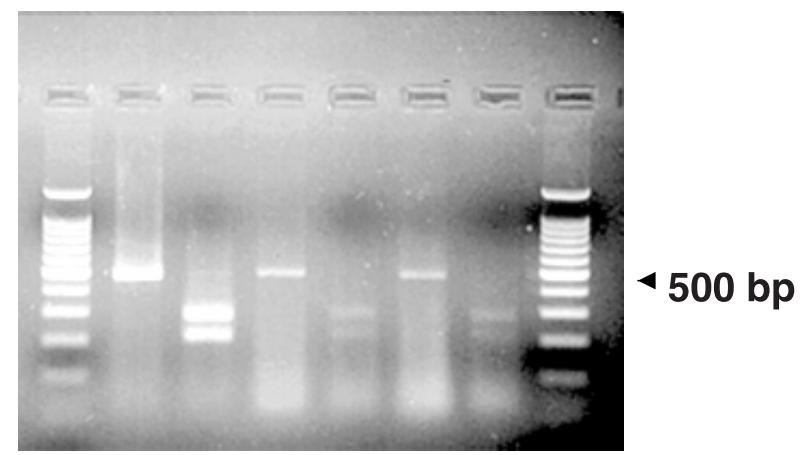

Figure 5 Agarose gel analysis of GH PCR products digested with Aval yielding two bands of 203 and $270 \mathrm{bp}$. Lane 1 and 8: $100 \mathrm{bp}$ ladder. Lane 2: undigested pituitary sample. Lane 3: digested pituitary sample. Lanes 4 and 6 represent undigested salivary samples from two GHRH-treated mice, and the corresponding digested products are shown in lanes 5 and 7.

from normal pituitaries (lane 2) were completely digested into two fragments of $203 \mathrm{bp}$ and $270 \mathrm{bp}$ respectively (lane 3). The same pattern of bands appeared when samples from submaxillary glands were tested (undigested samples: lanes 4 and 6; digested samples: lanes 5 and 7), confirming that submaxillary GH transcript is similar to that found in the normal pituitary gland.

\section{Discussion}

Adult rat salivary tissue submitted to the influence of high local GHRH concentrations was capable of synthesizing $\mathrm{GH}$ both in vivo and in vitro (Tresguerres et al. 1999a,b). The findings presented here confirm that such a GHinduction process also takes place in submaxillary cells from mice under the same experimental conditions. Moreover, using highly sensitive techniques such as RT-PCR followed by Southern blot, we have been able to demonstrate that salivary tissue also basally transcribes $\mathrm{GH}$ mRNA.

The basal GH expression by the submaxillary gland observed in our experiment is in agreement with other studies which describe extrapituitary GH synthesis in normal rat and human tissues as, for example, in the liver, kidney, muscle, gastrointestinal tract, lung and lymphocytes (Kyle et al. 1981, Weigent et al. 1991). The existence of an almost ubiquitous transcription of the $\mathrm{GH}$ gene has been suggested in a recent review by Harvey \& Hull (1997), and other authors have also commented that basal or low-level expression of GH could be seen in non-pituitary cells (Tuggle \& Trenkle 1996). The binding of ubiquitous transcription factors to the $\mathrm{GH}$ promoter or the absence of inhibitory elements which normally repress $\mathrm{GH}$ expression in non-pituitary cells could explain this 
extrapituitary GH transcription (Chelly et al. 1989, Tuggle \& Trenkle 1996). In addition to all these data supporting our findings, the submaxillary gland has been found to produce several hormones (renin, angiotensin II, glucagon, somatostatin, gastrin), and growth factors (epidermal growth factor, nerve growth factor and IGF-I) (Barka 1980, Ryan et al. 1992).

The basal transcription of the GH gene in mouse salivary tissue appears to be Pit-1 independent according to our results, since it was also found in submaxillary gland samples from Pit-1-deficient Ames dwarf mice. GH gene expression independent of Pit-1 has already been described in murine immune system cells (Weigent \& Blalock 1994, Kooijman et al. 1997), and pituitary-type prolactin gene transcription in human uterine cells has also been shown to be Pit-1 independent (Gellersen et al. 1995). Nevertheless, the subject cannot yet be fully explained.

When GHRH was locally administered at very high doses in normal mice, GH expression in the submaxillary gland was markedly increased, thus confirming the GHRH-dependent GH induction process previously described in the rat by our group (Tresguerres et al. 1999b). Several studies have previously suggested that GHRH could induce GH synthesis in tissues other than the pituitary (Leveston et al. 1981). This effect of GHRH on GH transcription was not observed in salivary tissue from Pit-1-deficient dwarf mice, which suggests that its influence on GH was at least partially mediated by Pit-1. However, we were also unable to detect Pit-1 expression by RT-PCR followed by Southern blot in salivary glands from normal mice treated with GHRH which had shown elevated GH contents. Therefore, other factors, such as those previously mentioned in relation to the control of the basal extrapituitary GH expression, could be implicated. Nevertheless, the absence of GHRH-induced GH expression in Ames mice remains to be clarified until new information becomes available.

While previous studies have failed to detect GH and Pit-1 mRNA in the pituitary glands of Ames dwarf mice (Slabaugh et al. 1981, Cheng et al. 1983), several recent reports have described the existence of GH- and Pit-1positive cells (Andersen et al. 1995, Gage et al. 1995, 1996) and Pit-1 mRNA (Camper et al. 1990) in pituitary glands from these animals. In agreement with the latter findings we have confirmed the expression of $\mathrm{GH}$ and Pit-1 in pooled pituitaries from Ames dwarf mice using RT-PCR followed by Southern blot. The differences in detecting GH and Pit-1 could be attributable to the different sensitivity of the methods employed by the researchers or the variations in different colonies of the dwarf mice.

In the present study, we have reported low but detectable levels of circulating GH and IGF-I. This observation contrasts with the results in the literature (Cheng et al. 1983, Chandrashekar \& Bartke 1993) in which these two hormones were not detectable by RIA in the circulation of the same kind of animals. Different methods used to measure these hormones could explain this discrepancy in the results. In this regard, Chandrashekar \& Bartke (1993) used cryoprecipitation to eliminate IGF-I binding proteins present in the plasma, whereas we used acid-ethanol extraction. Regarding plasma GH levels, a higher sensitivity in our mouse GH could explain the differences. Thus, Cheng et al. (1983) reported a sensitivity of $100 \mathrm{pg} /$ tube against $5 \mathrm{pg} /$ tube registered by us.

In conclusion, the present experiment confirms that adult submaxillary glands synthesize GH when they are exposed to the influence of high local GHRH concentrations. In addition, we have demonstrated that salivary tissue basally transcribes GH. Both basal and GHRHinduced salivary $\mathrm{GH}$ productions appear to be independent of Pit-1, although the reason why GHRH does not induce GH gene expression in Ames mice remains to be determined.

\section{Acknowledgements}

The authors wish to acknowledge NIDDK and Dr A F Parlow for supplying the reagents for the mouse GH assay and IGF-I antibody, Serono for kindly providing GHRH (1-29)- $\mathrm{NH}_{2}$ and somatostatin, and Eli Lilly Co. for supplying the IGF-I standard. The authors also thank L Kraus, A Carmona and B Martinez for their expert laboratory assistance. This work was supported by a grant from Fondo de Investigaciones Sanitarias (FIS 94/0389, Spain), and by a fellowship from Ministerio de Educación y Cultura (AP 92, Spain).

\section{References}

Altschul SF, Gish W, Miller W, Myers EW \& Lipman DJ 1990 Basil local alignment search tool. Journal of Molecular Biology 215 403-410. Andersen B \& Rosenfeld MG 1994 Pit-1 determines cell types during development of the anterior pituitary glands. A model for transcriptional regulation of cell phenotypes in mammalian organogenesis. Journal of Biological Chemistry 269 29335-29338.

Andersen B, Pearse RV, Jenne K, Sornson M, Lin SC, Bartke A \& Rosenfeld M 1995 The Ames dwarf gene is required for Pit-1 gene activation. Developmental Biology 172 495-503.

Bang P, Baxter RC, Blum WF, Breier BH, Clemmons DR, Hall K, Hintz RL, Holly JPM, Rosenfeld RG \& Zapf J 1995 Valid measurements of total IGF concentrations in biological fluids. Recommendations from the 3rd International Symposium on Insulin-like Growth Factors. Endocrinology 136 816-817.

Barka T 1980 Biologically active polypeptides in submandibular glands. Journal of Histochemistry and Cytochemistry 28 836-859.

Bartke A 1964 Histology of the anterior hypophysis, thyroid and gonads of two types of dwarf mice. Anatomical Record 149 225-236.

Bradford MM 1976 A rapid and sensitive method for the quantitation of microgram quantities of protein utilizing the principle of protein-dye binding. Analytical Biochemistry 72 248-254.

Camper SA, Saunders TL, Katz RW \& Reeves RH 1990 The Pit-1 transcription factor gene is a candidate for the murine Snell dwarf mutation. Genomics 8 586-590.

Cardinali DP, Esquifino AI, Arce A, Vara E, Ariznavarreta C \& Tresguerres JAF 1994 Changes in serum growth hormone and prolactin levels, and in hypothalamic growth hormone-releasing hormone, thyrotropin-releasing hormone and somatostatin content, 
after superior cervical sympathectomy in rats. Neuroendocrinology $\mathbf{5 9}$ $42-48$.

Chandrashekar V \& Bartke A 1993 Induction of endogenous insulinlike growth factor-I secretion alters the hypothalamic-pituitarytesticular function in growth hormone-deficient adult dwarf mice. Biology of Reproduction 48 544-551.

Chatelain PG, Van Wik JJ, Copeland KC, Blethen SL \& Underwood LE 1983 Effect of in vitro action of serum proteases or exposure to acid on measurable immunoreactive somatomedin C in serum. Journal of Clinical Endocrinology and Metabolism 56 376-383.

Chelly J, Concordet JP, Kaplan JC \& Kahn A 1989 Illegitimate transcription: transcription of any gene in any cell type. PNAS $\mathbf{8 6}$ 2617-2621.

Cheng TC, Beamer WG, Phillips JA, Bartke A, Mallonee RL \& Dowling C 1983 Etiology of growth hormone deficiency in Little, Ames, and Snell dwarf mice. Endocrinology 113 1669-1678.

Chomczynski P \& Sacchi N 1987 Single-step method of RNA isolation by acid guanidinium thiocyanate-phenol-chloroform extraction. Analytical Biochemistry 162 156-159.

Daughaday WH, Mariz ID \& Blethen SI 1980 Inhibition of access of bound somatomedin to membrane receptor and immunobinding sites: a comparison of radioreceptor assay of somatomedin in native and acid-ethanol extracted serum. Journal of Clinical Endocrinology and Metabolism 51 781-788.

Fernandez P, Granados B, Ariznavarreta C, Rodriguez-Ramos A, Gil-Loyzaga P \& Tresguerres JAF 1994 Rat parotid gland tissue is able to assume pituitary functions under hypothalamic extracts in culture. Neuroendocrinology 60(Suppl) 36.

Fox SR, Jong MTC \& Casanova J 1990 The homeodomain protein, Pit-1/GHF-1 is capable of binding to and activating cell-specific elements of both the growth hormone and prolactin gene promoters. Molecular Endocrinology 4 1069-1080.

Gage PJ, Lossie AC, Scarlett LM, Lloyd RV \& Camper SA 1995 Ames dwarf mice exhibit somatotrope commitment but lack growth hormone-releasing factor response. Endocrinology 136 1161-1167.

Gage PJ, Roller ML, Saunders TL, Scarlett LM \& Camper SA 1996 Anterior pituitary cells defective in the cell-autonomous factor, df, undergo cell lineage specification but not expansion. Development 122 151-160.

Gellersen B, Kempf R, Telgmann R \& DiMattia GE 1995 Pituitarytype transcription of the human prolactin gene in the absence of Pit-1. Molecular Endocrinology 9 887-901.

Goodfriend TL, Levine L \& Fasman GD 1964 Antibodies to bradykinin and angiotensin: a use of carbodiimide in immunology. Science 144 1344-1346.

Harvey S \& Hull KL 1997 Growth hormone. A paracrine growth factor? Endocrine 7 267-279.

Karin M, Castrillo JL \& Theill LE 1990 Growth hormone gene regulation: a paradigm for cell-type specific gene activation. Trends in Genetics 6 92-96.

Kooijman R, Malur A, Van Buul-Offers SC \& Hooghe-Peters EL 1997 Growth hormone expression in murine bone marrow cells is independent of the pituitary transcription factor Pit-1. Endocrinology 138 3949-3955.

Kyle CV, Evans MC \& Odell WD 1981 Growth hormone-like material in normal human tissues. Journal of Clinical Endocrinology and Metabolism 53 1138-1144.

Leveston SA, McKeel DW, Buckley PJ, Deschryver K, Greider MH, Jaffe BM \& Daughaday WH 1981 Acromegaly and Cushing syndrome associated with a foregut carcinoid tumor. Journal of Clinical Endocrinology and Metabolism 53 682-689.

Li S, Crenshaw EB III, Rawson EJ, Simmons DM, Swanson LW \& Rosenfeld MG 1990 Dwarf locus mutants lacking three pituitary cell types result from mutations in the POU-domain gene Pit-1. Nature 347 528-533.

Lima L, Arce V, Tresguerres JAF \& Devesa J 1993 Clonidine potentiates the growth hormone $(\mathrm{GH})$ response to $\mathrm{GH}$-releasing hormone in norepinephrine synthesis-inhibited rats. Evidence for an alpha-2-adrenergic control of hypothalamic release of somatostatin. Neuroendocrinology 57 1155-1160.

Linzer DI \& Talamantes F 1985 Nucleotide sequence of mouse prolactin and growth hormone mRNAs and expression of these mRNAs during pregnancy. Journal of Biological Chemistry 260 9574-9579.

Matsubara S, Sato M, Mizobuchi M, Niimi M \& Takahara J 1995 Differential gene expression of growth hormone (GH)-releasing hormone $(\mathrm{GRH})$ and GRH receptor in various rat tissues. Endocrinology 136 4147-4150.

Peter B, Man YM, Begg CE, Gall I \& Leader DP 1988 Mouse cytoskeletal gamma-actin: analysis and implications of the structure of cloned cDNA and processed pseudogenes. Journal of Molecular Biology 203 665-675.

Rol de Lama MA, Pérez-Romero A, Hermanussen M, Ariznavarreta C \& Tresguerres JAF 1998 Sexual dimorphism in growth as measured by microknemometry: different responses to GH defiency and exogenous GH administration. Neuroendocrinology 68 210-219.

Ruvkun G 1992 A molecular growth industry. Nature 360 711-712.

Ryan J, Mantle T, McQuaid S \& Costigan DC 1992 Salivary insulin-like growth factor-I originates from local synthesis. Journal of Endocrinology 135 85-90.

Sambrook J, Fritsch EF \& Maniatis T 1989 Molecular Cloning: A Laboratory Manual, edn 2. Cold Spring Harbor, NY: Cold Spring Harbor Laboratory Press.

Slabaugh MB, Lieberman ME, Rutledge JJ \& Gorski J 1981 Growth hormone and prolactin synthesis in normal and homozygous Snell and Ames dwarf mice. Endocrinology 109 1040-1046.

Sornson MW, Wu W, Dasen JS, Flynn SE, Norman DJ, O'Connell SM, Gukovsky I, Carriere C, Ryan AK, Miller AP, Zuo L, Gleiberman AS, Andersen B, Beamer WG \& Rosenfeld MG 1996 Pituitary lineage determination by the Prophet of Pit-1 homeodomain factor defective in Ames dwarfism. Nature 384 327-333.

Steinfelder HJ, Hauser P, Nakayama Y, Radovick S, McClaskey JH, Taylor T, Weintraub BD \& Wondisford FE 1991 Thyrotropinreleasing hormone regulation of human TSH- $\beta$ expression: role of a pituitary-specific transcription factor (Pit-1/GHF-1) and potential interaction with a thyroid hormone-inhibitory element. PNAS 88 3130-3134.

Thorell SL \& Johansson BG 1971 Enzymatic iodination of polypeptides with ${ }^{131} \mathrm{I}$ to high specific activity. Biochimica et Biophysica Acta 251 363-366.

Tresguerres JAF, Ariznavarreta C, Granados B, Alvarez-Vega P, Fernandez-Mateos P, Gil-Loyzaga P \& Alvarez-Buylla R 1999a Parotid gland tissue is able partially to assume pituitary functions under the influence of hypothalamic factors: in vivo and in vitro studies. Journal of Endocrinology 160 205-216.

Tresguerres JAF, Ariznavarreta C, Granados B, Costoya JA, Perez-Romero A, Salame F \& Hermanussen M 1999b Salivary gland is capable of GH synthesis under GHRH stimulation. Journal of Endocrinology 160 217-222.

Tuggle CK \& Trenkle A 1996 Control of growth hormone synthesis. Domestic Animal Endocrinology 13 1-33.

Weigent DA \& Blalock JE 1994 Effect of the administration of growth-hormone producing lymphocytes on weight gain and immune function in dwarf mice. Neuroimmunomodulation 1 50-58.

Weigent DA, Riley JE, Shawn Galin F, LeBoeuf RD \& Blalock JE 1991 Detection of growth hormone and growth hormone-releasing hormone-related messenger RNA in rat leukocytes by the polymerase chain reaction. Proceedings of the Society for Experimental Biology and Medicine 198 643-648.

Received in final form 31 October 2000

Accepted 31 January 2001 